\title{
The Absence of the Rose
}

\author{
The Symbolic Meaning of "Rose" in William Faulkner's A Rose for Emily
}

\author{
Fanting Kong \\ Yantai Nanshan University \\ Yantai, China
}

\begin{abstract}
A Rose for Emily is William Faulkner's typical short novel. It is a story without rose. "Rose" has very deep symbolic meanings in the novel. It connects with the theme and characteristics of the heroine closely. This paper tries to analyze the symbolic meanings of the rose and disclose the inevitable causes of Emily's tragedy character distortion.
\end{abstract}

Keywords -rose; symbolic meanings; tragedy

\section{INTRODUCTION}

Like so many American writers, Faulkner finds himself again and again writing short stories. Some of which are considered as equally important as his best novels. Good as his short stories are, they seem always at the threshold of being absorbed into the Yoknapatawpha saga - that legendary matrix which is Faulkner's real achievement. A Rose for Emily is Faulkner's first short story published in 1930. Set in the town of Jerrerson in Yoknapatawpha, the story focuses on Emily Grierson, an eccentric spinster who refuses to accept the passage of time, or the inevitable change and loss that accompanies her. Simple as it is in plot, the story is pregnant with meaning. "As a descendant of the Southern aristocracy, Emily is typical of those in Faulkner's Yoknapatawpha stories who are the symbols of the Old South but the prisoner of the past" (Zhang 611). In this story, Faulkner makes best use of the symbolic technique in narration. "He seldom put emphasis on reality, but on symbolic approach to literature in order to discover the truth of the human heart" (Wu 199). In this novel, the "rose" is absent. Where is the "rose"? What are the symbolic meanings of the "rose"? What is the relationship between the "rose" and Emily? These questions will be discussed in detail in the paper.

\section{BRIEF INTRODUCTION OF THE AUTHOR AND THE NOVEL}

"There is no region in the U.S. that contains as much beauty, violence, passion, courage and finally, tragedy as the American south. And in the twentieth century, there is no novelist who more powerfully and eloquently represents this region in his fiction than William Faulkner" ( Peide, qtd. in Xiao 136 ).

William Faulkner is regarded as one of the leading American authors of the Twentieth Century and the leading representative of "Southern Literature". His writings draw the attention not only the Americans but also the whole world. In his circle Faulkner truthfully presents the transition of the south society, the decline of the southern plantations and the consequence of modern industrialization. And his works reflect the psychology of the Southerners in the transitional period-the loneliness and rootlessness of the southern descendants when they were faced with the uncontrollable devastation of the south tradition and the advancement of North Industrialization. From many aspects, he is an original writer. His subject matter, his originality of working out the plot, and his unusual artistic style let him stand like a firm and erect reef in the fast changing western literary currents. It is owing to his outstanding contribution to world literature that he was awarded the Nobel Prize for literature in 1950.

A Rose for Emily is among Faulkner's best novels for his "Yoknapatawpha Kingdom". This novel demonstrates some of Faulkner's artistic preoccupations: the exploration of the social structure and custom of a southern community, the feelings of loneliness and rootlessness of the southern descendants, the uncontrollable devastation of the Southern tradition.

The story sets in the town of Jefferson in Yoknapatawpha country, the center of Faulkner's "mythical kingdom", and Emily Grierson, a descendant of the noble Grierson family, is the central character of the short story. Dominated by her father who bore the rigid ideas of social status, the daughter has been prevented from marrying her town fellows during his lifetime, and therefore after his death, she is left alone and penniless. Later, she falls in love with a Yankee, Homer Baron, which is disregarded by the whole town and her relatives. As a member of the stubborn Grierson's family, Emily arrogantly defies her kin and the community by insisting on marrying Homer. Unfortunately, Miss Emily finds that Homer has no intention to marry her. Desperately, Miss Emily kills her lover and keeps his body. Since then, Emily isolates herself from the outside world and lives lonely in her house until her death.

\section{THE SyMbOLIC MEANINGS OF THE ROSE IN WESTERN CULTURE}

In western culture, the rose has three important symbolic meanings. Firstly, the rose means Jesus' blood, and it stands for the love and respect for God. Secondly, the rose means Adonis's blood, and it stands for the tragic love beyond death and space-time. Thirdly, the rose means Eros, and it stands for earthly love.

In the novel "A Rose for Emily", "Rose" contains all these symbolic meanings. The following passage will discuss these 
things in detail and present the relationship between the rose and Emily, thus we can deeply understand the theme and personality of the heroine.

\section{THE LOVE AND RESPECT FOR GOD}

Rose stands for Jesus' blood, and it means the love for God and a feeling of admiration and respect. It is a complicated feeling of the townspeople in Jefferson to Emily. It implies that Emily's life is just like a rose, which remains in the memory of the people in Jefferson Town from generation to generation.

\section{A. The Representative of the South Tradition}

In this novel, Emily is set as a monument, the symbol of a tradition, a class, a way of life and certain values. She is born into the noble, white, declining Grierson family. Though the family is not as rich in material life as before, it stubbornly tries to keep the fame of the noble family. Mr. Grierson in his lifetime prevented any town youth from marrying her daughter, for the young men are not from a distinguished family like the Grierson. As the town people commented, "The Grierson held themselves a little too high for what really were. None of the young men were quite good enough to Miss Emily and such" (Faulkner 103). After her father's death, Emily still lives under his father's shadow, and also the shadow of her aristocratic family - the Grierson. She refuses to dispose of her father's body after his death and she puts her father's portrait in an eyecatching place, because it is her connection to her past. Emily maintains her aristocratic dignity. When the town representatives visit her for tax affair, she receives them calmly while coldly. Her coal-like eyes "moved from one face to another while the visitors stated their errand" (Faulkner 101). Emily is a representative of the southern tradition and the southern aristocratic family - arrogant, cold, standing high above others. She is the connection of the town people with the old south tradition, so "when she died, our whole town went to her funeral: the men through a sort of respectful affection for a fallen monument"(Faulkner 99), and "the very old men-some in their brushed Confederate uniforms - stand on the porch and the lawn, talking of Miss Emily as if she had been a contemporary of their [...]"'(Faulkner 110). For the town people, she is the symbol of the old times, and her death signifies the fall of monument - the fall of the old tradition.

Emily is respected as a monument by townspeople. Homer Barron is an unheroic figure who puts too much dependence upon his self-centered and rootless philosophy, a belief which suggests that he could take whatever he wants without considering any obligation to the past (tradition) or to the future (death). Emily's resistance is heroic. Her tragic flaw is the conventional pride: she undertakes to regulate the natural time-universe. She acts as though death did not exist, and as though she could retain her unfaithful love by poisoning him and holding his physical self prisoner in a world which has all of the appearances of reality except the most necessary of all things-life. Because Homer is dead, he could not marry Miss Emily, and then the monument continues to exist in the south people. In fact, the two generations ignore the real Emily, but create and maintain the myth of Emily as an example of southern womanhood from a last age.
"Alive, Miss Emily had been a tradition, a duty, and a care" (Tao 130). When she dies, our whole town goes to her funeral, that's why Faulkner presents "a rose for Emily."

\section{B. The Complicated Feelings of the Townspeople in Jefferson to Emily}

Emily is never laughed at or treated with contempt or disgust. "The rose in the title indicates, as the tone of the story insinuates, a feeling not altogether unfriendly, one probably of compassion" (Chang 243). Thus, people view her with sympathy and a sort of respect though her personality is twisted and her action is grotesque. That's why when her father dies "all the ladies prepared to call at the house, and offer condolence and aid" (Faulkner 104) and when she falls in love with Homer, people say "Poor Emily". Because she possesses something peculiar to aristocrats in her character, such as the honor, pride, dignity, courage, serenity and elegance, which, in a sense, people take pride in and cherish but seem to be lost in contemporary days, people show respect for her. The title A Rose for Emily implies that Emily is worthy of memory of a "rose"; the use of the two roses in the following " $[\ldots]$ the valance curtain of faded rose color $[\ldots]$ the rose-shades lights [...]" (Faulkner 111) also conveys a sense of respect. This is why when Emily dies her funeral is rather solemn: "when Miss Emily died, our whole town went to her funeral: the men through a sort of respect affection for a fallen monument" (Faulkner 99). For the old men, they regard her as a part of their own glorious history. Therefore, though no one has seen the upstairs room in forty years, "they waited until Miss Emily was decently in the ground before they opened it" (Faulkner 110). It seems that they have admitted that she has the right of seclusion, and can go on with it until she dies.

Emily is an ugly, old woman. But in the eyes of the old generations, she is like an angel. As a "monument", Emily is a religious symbolic heart of the old generation in spite of her spiritual deterioration stemming directly from the loss of love.

Emily is "tranquil and perverse", proud and aloof, a representative of traditional convention. She is just like a rose, which remains in the memory of the people in Jefferson Town from generation to generation, and she is worthy of this memory. So people present "a rose for Emily".

\section{The Tragic Love Beyond Death AND SPACE-TIME}

Rose stands for Adonis's blood. Adonis and Venus's tragic love story is well-known, and the tragedy ends with the appearance of the rose and the death of the hero. It is destined to be a tragic love with blood and that is the portrayal of Emily.

\section{A. The Destined Tragic Love}

The whole story centers on Emily's love tragedy. The way Emily tries her utmost to conquer love is very grotesque. Emily poisons her lover and keeps his corpse for 40 years. Since then, she loses her love and happiness during her lifetime. Her love is doomed to be a tragedy.

1) Her doomed tragedy by the traditional values and education: When she falls in love with the Yankee, she "carried her head high enough" (Faulkner 106) in spite of all 
the rumors against her. She is the representative of the old values, but once she is in conflict with the society as an individual, she is in defiance of the traditional moral values unconsciously to seek for the realization of her value as an independent individual. Yet, when she succeeds in putting her will upon most people and let them accept the fact that she is going to be married, Homer Barron is going to desert her. She cannot bear such betrayal of her, which is against her will, so she kills him in order to own him. The traditional education she receives makes her form such an idea: one's lover is like his private possessions. If she cannot get him, she will use violence to achieve her purpose. Since then, she loses her lover and happiness forever. She is absolutely desperate. Emily's strong-willed personality and the traditional value and education cause her tragedy.

2) Her doomed tragedy by the different values in the south and the north: Emily and Homer come from different world. "Alive, Miss Emily had been a tradition" (Tao 130), her death is "a fallen monument". So Emily is regarded as a symbol of the traditional south and its value. And Homer Barron, a Yankee, "with niggers and mules and machinery," is a symbol of the industrial North and its value. In paragraph two of section one, there is a vivid picture about the serenity and elegance of Miss Emily's neighborhood which has been destroyed by obvious symbols of mechanization: the cotton gin and gasoline pumps. And Homer's construction company coming to the town according to "the contracts" further implies the historical fact that the North expanded its force to the South after winning the Civil War. Under the new condition (Emily's father's death can be considered as the collapsing of the southern slavery system) Emily (the South) accepts Homer (the North) because of being seduced by this "big, dark, ready" Yankee. It is not long after they are in love that Emily finds Homer (the North) cannot be depended on (that he was not a marrying man). Since they cannot be unified forever, the South, which is deceived, has to struggle to resist the progressive and materialistic civilization of the North. From these points of view, Emily and Homer can never be getting together forever, and Emily is doomed to have a tragic love.

3) Her doomed tragedy by the moral confusion and different ideologies: We realize that the sharp conflict between the two different types of social ideologiescapitalism and slavery - the root of Emily's tragedy. When Faulkner is exploring the problems of concepts and code of ethics, he has felt that modern western society is in the state of moral confusion, lack of social moral standards and disciplines. There the standards are to pursue private ends. The foreman, Homer Barron, is a typical character who carries the kind of Bourgeois moral values. He seeks for private interest and lacks moral disciplines; he indulges in wine and women but refuses to bear any moral responsibilities. He dates Miss Emily overtly but "was not a marrying man". $\mathrm{He}$ is not serious about love. He just flirts. With Emily-a representative of the old moral values, Homer's moral values form a sharp contrast with hers, so they cannot be together; yet, unfortunately, she falls in love with him. It is the tragedy. She cannot endure his behavior, so the conflict between them develops, and finally to the degree of climax. The only way of solving the conflict is using violence - to kill him. "It is not the author who likes violence, but the result of conflicts, to be more exact, the result of moral confusion"(Weinstein 83). It is inevitable.

It is the old decayed south tradition, the conflict between the south and north values and the moral confusion that are responsible for Emily's destined tragic love and miserable life.

\section{B. The Challenge of the Time, Reality and Death}

Though time has changed and society is advancing, Emily still lives in the past. She doesn't accept the passage of time, nor the changes, nor the inevitable loss that accompanies it. For example, she refuses to pay the tax and says "see Colonel Sartoris, I have no taxes in Jefferson"(Faulkner 102). In fact, Colonel Sartoris has been dead almost ten years. To Miss Emily, time is dead, never fluid and already stops in the past and will remain there forever, therefore things will not change but remain the same as they were before. Yet, society is inevitably changing with time. Her attitude to the change makes her incompatible with the surroundings. Everything but she is changing, even her house is left among the "cottonwagons" and "gasoline pumps". She cannot adapt herself to the realistic life, so she lives a reclusive life. She does not want to communicate with the outside world and tries to cut off all connections with society. Only by doing so can she lightens a little the pressure put on her by the outside world. Though she wants to, she cannot completely and really escape from society. As a human being, one inevitably has a thousand and one links with the community in which he is part of, so does Emily. Time is still flowing away, and no one can stop the pace of history. Miss Emily, the old southern aristocrats, tries her best to challenge to the time and reality, finally becomes "a fallen monument", and the old south, which carries a moral burden of quilt about slavery, cannot keep itself from declining and disintegrating. "Whoever tries to stop history from advancing will be crushed under the wheels of history"(Li 320). Emily's challenge is failing and to some extent meaningless. But to her it is different. She fixes herself in the moment that she falls in love with Homer and she can love him forever even though she only keeps his corpse.

If we relate the rose to the "smell" which comes out from Emily's house, the implication will be more evident. To those who know English very well, the moment between "rose" and "smell" is mentioned.

Emily poisons her lover and keeps his corpse. And the bad smell from the corpse makes her neighbor unbearable, even disturbs the court. Finally, Judge Stevens has to send four men to sprinkle lime at night. If Emily were a rose, the bad smell could not damage her image. In order to gain love she has to put all her eggs in one basket to poison her lover. Keeping the corpse is her challenge to time, death, and frequent changes. If Homer's death and blood were a rose, Emily remains the rose forever without considering the time and enjoys the "bad smell". For her, the rose never fades but always smells sweet. 


\section{THE PURSUIT OF THE EARTHLY LOVE}

Look at the title A Rose for Emily, rose and Eros have the same pronunciation. So the title can be Eros for Emily. Actually, it is a story without rose but a description of Emily's grotesque characteristic and her ill-sexed psychology. Homer Barron, Emily's lover, is similar to "home"; it indicates such a meaning that Emily keeps him at home all the time. Thus the horrible end will not shock us.

\section{A. The Cause of Her Ill-sexed Psychology}

Emily is "tranquil and perverse", proud and aloof, a representative of traditional convention. She is a woman who experiences a miserable life, her tragedy is unchangeable and nobody could help her.

Emily Grierson, who was born in a decayed aristocratic family, is a victim. When she is very young, she is dominated by her father and his rigid ideas of social status, as the town people describes: "we had long thought of them as a tableau, Miss Emily a slender figure in white in the background, her father a straddle silhouette in the foreground, his back to her and clutching a horse whip, the two of them framed by the back-flung front door" (Faulkner 104). From this we can see her father is like a guard who tries to drive away anyone or anything that is against the traditional morals and conventions so as to keep Emily following his rigid ideas of social status. Her father is a representative of the decayed aristocrats' old values: "the Grierson held themselves a little too high for what they really were, none of the young man was quite good enough for Emily and such" (Faulkner 103). Her father drives away all the young men; it is her father who deprives Emily of her youth, love and happiness. When she is about thirty she is still single, and after her father's death she is left alone and penniless. Her dependence on her father continues even after his death. She refuses to release his body for Burial; she keeps his portrait in a prominent place in her living room. As the narrator points out: "she would have to cling to that which had robbed her, as people will" (Faulkner 108). Emily not only clings to her father's memory but also becomes the representative of the old moral values, which are deep-rooted in her mind under her father's long influence and land her in a tragic life. Emily is not only under her father's peremptory domination but also under the social pressure because she is born in a noble family. So we can naturally understand the abnormal phenomenon of Emily's grotesque personality and ill-sexed psychology and deeply master the root of her tragic life.

\section{B. The Cause of Her Tragic Life}

On the other side, the writer lively portrays Emily as a strong figure in the tragedy. Her strong personality can be well reflected from two episodes. One is that she refuses to pay taxes; she not only ignores the tax notice from the government, but also sends it back without any comment. She even vanquishes the deputation "horse and foot." The other is that she buys poison and offers no explanation in the drug store.

Emily's strong-willed personality and her strong desire for love make her bravely pursue the love. Only after her father's death does she begin to have the right to love. "In the summer after her father's death, she has her hair cut short and looks like a little girl" (Faulkner 105). Soon she falls in love with Homer, "a Yankee", "a northerner", and "a day laborer". She carries her head high in "her dignity" as the last Grierson though the community "believed that she was fallen".

Emily's love affair is not affected by her two female cousins' interference. But more than one year after she is in love with Homer, she finds that he is not a marrying man and fails in convincing him to marry her. In order to keep the precious love, her strong desire for love and strong-willed personality make her take the risk of poisoning her lover and embraces his corpse to release her lust. The experience drives her to get mental problem and psychological metamorphosis.

Emily's peremptory father should be mainly responsible for all the consequences, but her status and social pressure are also important factors. Besides, Emily is such a typical tragic heroine who persists in her idea or belief that she cannot think about things from another view. All these things are doomed to her tragic life. Emily can never get the rose (Eros) during her lifetime. Emily, like other common woman, just wants to love and be loved, so none of her eccentricities and serious mental illnesses are ridiculed or treated with contempt or disgust. Instead, they win sympathy and respect.

\section{CONCLUSION}

A Rose for Emily is William Faulkner's typical short novel. It is a story without rose. "Rose" has very deep symbolic meanings in the novel. It connects with the theme and characteristics of the heroine closely. In western culture, firstly, the rose stands for Jesus' blood, meaning the love for God and a feeling of respect. Emily is the monument of the south tradition; she is the angel in southern people's heart. The townspeople respect her and show sympathy for her. Secondly, the rose stands for Adonis's blood. Emily's love is destined to be a tragedy. The old south tradition and the different values of the South and the North are the roots of Emily's tragedy. Finally, the rose stands for Eros; it means the earthly love that Emily can never obtain. The shadow of her father and social status deprives her normal right and way of pursuing love. Emily's tragedy is mainly caused by the decayed south values and tradition. The loss of the south tradition and the appearance of the north industrialization arouse not only the devastation of the southern plantation system, but also the macabre disillusionment to the southern descendants. Faulkner shows Emily's efforts to hold to the south tradition and her sufferings in facing the conflicts between the southern plantation system and the north industrialization. At the same time, Faulkner presents delicately the spiritual pains of the descendants of the south plantation families, the conflicts of men with each other, with themselves in facing the new industrialization. "The decline and death of Emily predicate the conflict between the old tradition and the new order in the south and the disillusionment of the southern descendants in the conflict" (Tong 423). All these implied things are hidden in the bloody and beautiful flower - the "Rose".

Faulkner's novel is simple in plot but pregnant with meaning. The research on his works is not complete and 
enough. We need a thorough and deeper study so as to get the most essential understanding.

\section{REFERENCES}

[1] Faulkner, William. Collected Stories. New York: Random House, 1950.

[2] Weinstein, Philip M., ed. William Faulkner. London: Cambridge UP, 2000.

[3] Chang Yaoxin. Selected Reading in Ameican Literary Criticism [M]. Tianjin: NanKai University Press,1993.

[4] Li Wenjun. Collection of Commentaries on Faulkner [M]. BeiJing: China Social Sciences Publishing House, 1980.

[5] Liu Lili. Text Analysis of Foreign Classic Short Stories [M]. BeiJing: BeiJing University Press, 2004.

[6] Tao Jie. Faulkner literature Works [M]. Shi Jiazhuang: HeBei Education Press, 1995.

[7] Tong Ming. A History of American Literature [M]. NanJing: Yilin Translation Publishing House, 2002.

[8] Wu Dingbai.The Outline of American Literature [M]. ShangHai: Shanghai Foreign Language Education Press, 1998.

[9] Xiao Minghan. Studies of William Faulkner [M]. BeiJing: Foreign Language Teaching and Research Press, 1997.

[10] Zhang Boxiang. Selected Readings in English and American Literature [M]. BeiJing: Foreign Language Teaching and Research Press, 1999. 